\title{
CONFLICT MANAGEMENT MODEL OF FINANCIAL ACCOUNTING SYSTEM: APPLICATED IN SEMARANG REGIONAL GOVERNMENT
}

\author{
Saifudin ${ }^{1 *}$ \\ Ardiani Ika Sulistyawati ${ }^{2}$ \\ Universitas Semarang \\ Accepted: August 2020, Approved: September 2020, Published: October 2020
}

\begin{abstract}
The purpose of this study was to determine the effect of organizational behavioral factors, cognitive and affective conflict against regional financial accounting system usefulness and behavioral factors influence the organization of cognitive and affective conflict and behavioral factors influence the organization of the usefulness regional financial accounting system intervening by the presence of cognitive and affective conflict. The influence of behavior factors were superiors' support, clarity of purpose and training. The study was conducted at the sub-district and department employees in Semarang. The population is some sub-district and department employees who work on the financial section. Analysis of the data in this research was using Partial Least Square (PLS) method. The results of this study indicate a positive influence of organizational factors on the usability of Regional Financial Accounting System and cognitive conflict and there is a positive effect of cognitive conflict with usability Regional Financial Accounting System. Organizational factors negatively affect affective conflict and affective conflict negatively affects the usefulness of Regional Financial Accounting System..
\end{abstract}

Keywords: Organizational Behavior Factor, Conflict Cognitive, Affective Conflict, Financial Accounting System.

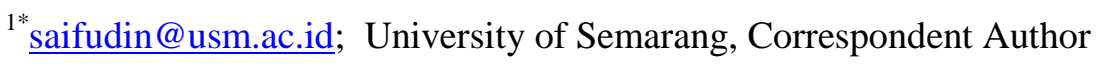
2ardiani@usm.ac.id; University of Semarang
} 


\section{INTRODUCTION}

Regional autonomy is part of democratization in creating a power share system at every level of government and demands the independence of the management system in the region. The distribution of authority / power is adjusted to the national and local authorities, including the financial authority. To make economic, social, and political decision, the accounting information is needed, one form of which is financial statements to achieve good government.

If we see the financial report of local governments in Indonesia, the government's financial report in Indonesia is something interesting to study further. This is because financial report in Indonesia is used as a means to commit deceitfulness or "fraud". From various writings that researcher found from the internet, it seems that in SKPD and local government financial statements there are still many data that do not fit presented. In addition, there are many deviations found by BPK in the financial statements audit of local governments, especially in Semarang government. According to Ilya Avianti, the deviations usually occur in the preparation of budget, the use of budgets and the financial reports which are manipulated. The deviations happen due to the lack of regulations and legislation as well as the limited ability of the government's human resources.

Based on the above cases, to achieve Good Governance, the government continues to intensify the steps in managing local financial. This system is in line with the laws that have been issued by the government that shows the State financial management reformation. The laws are the Law No. 17 of 2003 on State Financial, Law No.1 of 2004 on State Treasury, Law No. 15 of 2004 on Investigation of Management and Responsibility of State Financial. Law No. 32 of 2004 on Regional Government, Law No. 33 of 2004 on Financial Balance between Central and Regional Government, Government Regulation No. 24 of 2005 on the Management of Central and Regional Financial. Government Regulation No. 24 of 2005 on the Government Accounting Standards, Government Regulation No. 58 of 2005 on Regional Financial Management, Minister of Domestic Affairs Regulation Number 13 of 2006 on the guidelines of Regional Financial Management. The issueance of Minister of Domestic Affairs Regulation No. 59 of 2007 revised The Regulation of Minister of Domestic Affairs No. 13 of 2006 on the guidelines of Regional Financial Management. The various laws and regulations above are expected to be a solid foundation for the management of state financial to make good governance 
and clean government.

According to Chenhall (2004) in Jamila (2010) attitudes factors related to the success of $\mathrm{ABCM}$ application is central management support, linked to competitive strategy, adequacy of resources, accountant proprietary, relationship with evaluation of performance and compensation, training procurement, the clarity of goal and the number of purposes for ABCM. The important dimensions of organization factor are superiors' support, clarity of purpose and training.

\section{THEORETICAL BACKGROUND}

\section{A. Framewrok}

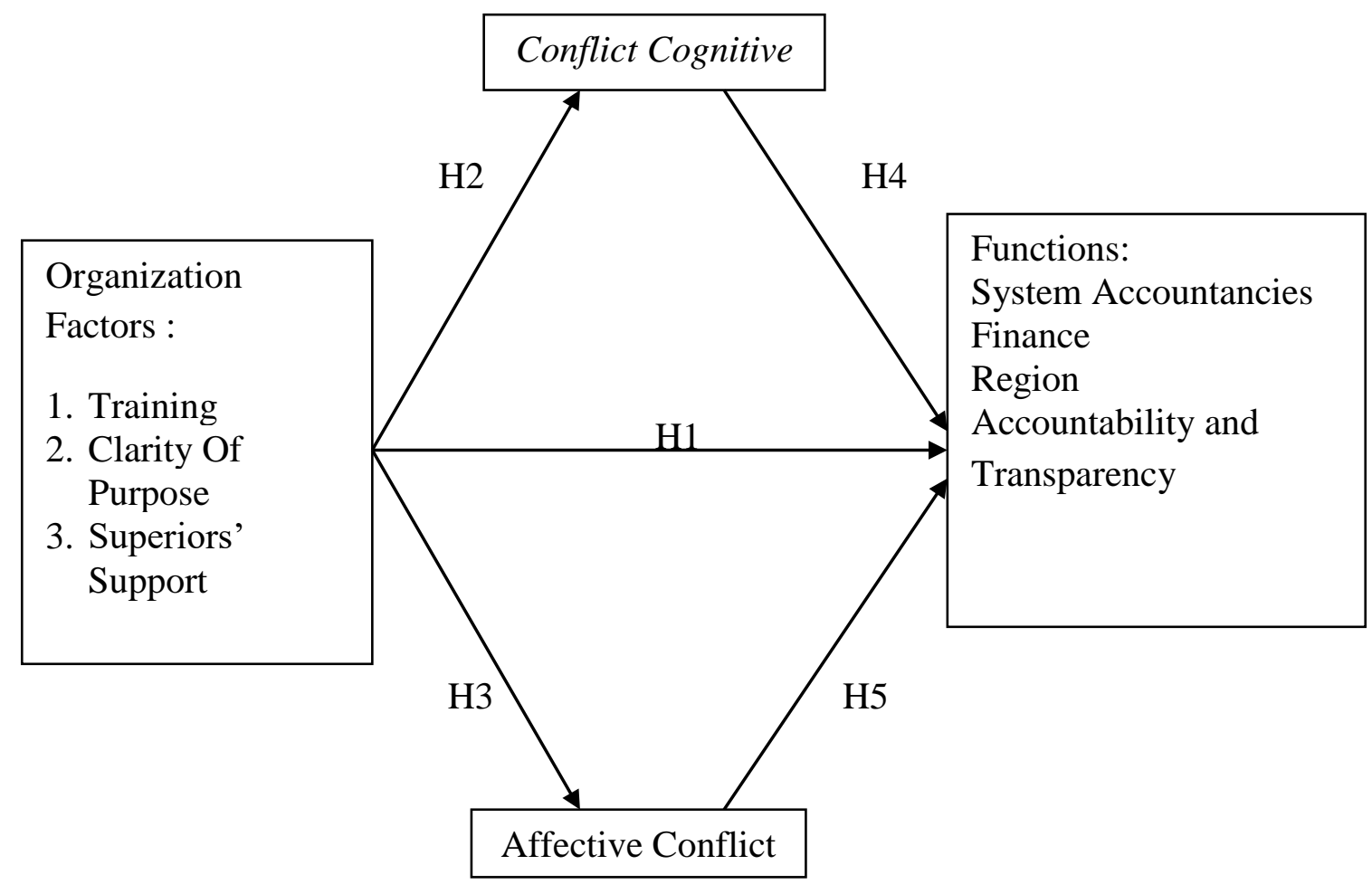

Figure 1

Framework 


\section{METHOD, DATA AND ANALYSIS}

\section{A. Research variable}

The research variables are the objects of research or what becomes the focus point of a researcher (Arikunto, 2006). Analysis of data in this study used the variables consisting of dependent variable, independent variable and intervening variable. Independent variables in this study are Organizational Factors that includes training, superiors' support, and clarity of purpose. Dependent variable in this study is Regional Financial Accounting System. Intervening variable are 1) Affective, 2) Cognitive

\section{B. Population and Samples}

Population is the totality of all possible values, whether the results of counting or qualitative measurement of the specific characteristics of all members of complete and clear group we want to learn its nature. In this case the study population was all districts in Semarang. Samples are half or representative of the population studied (Arikunto, 2008). Samples are taken since in many cases it is not possible for us to investigate all members of the population; therefore we establish a representative called samples (Ferdinand, 2006). But in this study the samples studied are of overall employees of district and financial department employees in Semarang.

\section{Inquiry or Questionnaire Method}

Questionnaire is a number of written questions that are used to obtain information from respondents in terms of reports on their personal or things to know (Arikunto, 2006). In this study the questionnaire used is closed questionnaire that is questionnaires in which the answers have already been provided so that the respondents just need to choose.

\section{Analysis Method}

The dependent variables in this research are the organizational factors that include: (1) Training; (2) Superiors' support; (3) Clarity of purpose. Meanwhile the independent variable in this study is Regional Financial Accounting System and the intervening variables in this study are the affective and cognitive.

The research was conducted in the District and the Department throughout the city of Semarang where the research objects of this study are employees of the District and the 
Department in charge of financial sector. The method of data collection / dissemination of the questionnaire used convenience sampling. While, the data analysis used in this study was Partial Least Square (PLS). PLS can be used on any kind of data scale (nominal, ordinal, interval, ratio) and a more flexible assuming requirement. PLS was also used to measure the relationship of each indicator with their constructs.

\section{RESULTS AND DISCUSSION}

\section{A. Validity Result}

Validity result can be seen in the table below:

Table 1

Validity Test Results

\begin{tabular}{|c|c|c|}
\hline Variable & Cross loading & Criteria \\
\hline DA1 & 0.541839 & \multirow{28}{*}{$\begin{array}{l}\text { Loading factor score must be } \\
\text { greater or over than } 0.50 \text { as } \\
\text { valid score }\end{array}$} \\
\hline DA2 & 0.608690 & \\
\hline DA3 & 0.535131 & \\
\hline DA4 & 0.507222 & \\
\hline DA5 & 0.636605 & \\
\hline KA1 & 0.598270 & \\
\hline KA2 & 0.997524 & \\
\hline KA3 & 0.509177 & \\
\hline KK1 & 0.589318 & \\
\hline KK2 & 0.594425 & \\
\hline KK3 & 0.788021 & \\
\hline KK4 & 0.532381 & \\
\hline KK5 & 0.644288 & \\
\hline KK6 & 0.560344 & \\
\hline KK7 & 0.614965 & \\
\hline KK8 & 0.553614 & \\
\hline KK9 & 0.672296 & \\
\hline KSAD1 & 0.747358 & \\
\hline KSAD2 & 0.633053 & \\
\hline KSAD3 & 0.740212 & \\
\hline KSAD4 & 0.655744 & \\
\hline KSAD5 & 0.607425 & \\
\hline KSAD6 & 0.759121 & \\
\hline KSAD7 & 0.712619 & \\
\hline KSAD8 & 0.748900 & \\
\hline KSAD9 & 0.634873 & \\
\hline KT1 & 0.636714 & \\
\hline KT2 & 0.526670 & \\
\hline
\end{tabular}




\begin{tabular}{ll}
\hline KT3 & 0.510391 \\
KT4 & 0.692071 \\
KT5 & 0.670957 \\
KT6 & 0.671265 \\
KT7 & 0.585579 \\
KT8 & 0.552323 \\
KT9 & 0.529668 \\
P1 & 0.531336 \\
P2 & 0.538376 \\
P3 & 0.567549 \\
P4 & 0.552408 \\
P5 & 0.674480 \\
\hline ource: Primary data analysis $(2013)$
\end{tabular}

According to table 1.2 above, it can be seen that factor loading or cross loading 0.7 indicates valid score. Some variables 0.5 until 0.6 indicate valid score.

\section{B. Reliability Test}

The reliability test can be seen on Composite Reliability score:

Table 2

Reliability Test

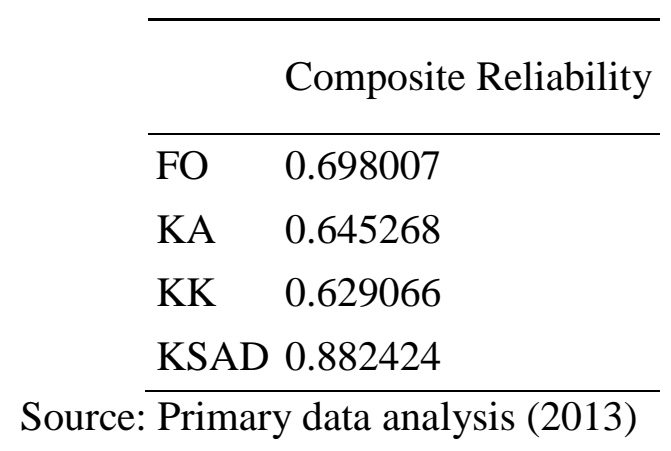

According to table 1.3 above, it can be seen that Composite Reliability score greater than 0.6 indicates that it's reliable. 


\section{Hypothesis Test Result}

The hypothesis test result used PLS data can be seen as follows:

Tabel 3

Path Coefficients (Mean, STDEV, T-Values)

\begin{tabular}{lllll}
\hline & $\begin{array}{l}\text { Original } \\
\text { Sample }(\mathrm{O})\end{array}$ & $\begin{array}{l}\text { Sample Mean } \\
(\mathrm{M})\end{array}$ & $\begin{array}{l}\text { Standard Deviation } \\
(\mathrm{STDEV})\end{array}$ & $\begin{array}{l}\text { Standard Error } \\
(\mathrm{STERR})\end{array}$ \\
\hline FO -> KA & -0.355888 & -0.317836 & 0.273219 & 0.273219 \\
FO -> KK & 0.575391 & 0.613601 & 0.085583 & 0.085583 \\
FO -> KSAD & 0.370960 & 0.377384 & 0.154292 & 0.154292 \\
KA -> KSAD & -0.184310 & -0.155442 & 0.136179 & 0.136179 \\
KK -> KSAD & 0.316308 & 0.320568 & 0.195684 & 0.195684 \\
\hline
\end{tabular}

Source: Primary data analysis (2013)

Table 4

Statistic T Value

\begin{tabular}{ll}
\hline & T Statistics $(|\mathrm{O} / \mathrm{STERR}|)$ \\
\hline FO $->$ KA & 1.702577 \\
FO $->$ KK & 6.723176 \\
FO $>$ KSAD & 2.404270 \\
KA $->$ KSAD & 1.753443 \\
KK $\rightarrow$ KSAD & 1.676421 \\
\hline
\end{tabular}

Source: Primary data analysis (2013)

H1Testing is: "The Organizational Factors such as Superiors' Support, Clarity of Purpose and Training give positive effects on the usefulness of Regional Financial Accounting System". The parameter coefficient is 0.370960 which means there is positive effect of the organizational factors on the usability of Regional Financial Accounting System. The higher the organizational factors, the higher the uasability of Regional Financial Accounting System with statistic t value of $2.404270>\mathrm{t}$ table (significance 5\% $=1.67)$ so that hypothesis is accepted. This means organizational factors give positive effects on the usability of Regional Financial Accounting System.

H2 Testing is: "The Organizational Factors such as Superiors' Support, Clarity of Purpose and Training give positive effects on cognitive conflict". The parameter coefficient is 0.575391 which means there is positive effect of Organizational Factors on 
cognitive conflict. With its statistic $\mathrm{t}$ value of $6.723176>\mathrm{t}$ table (significance $5 \%=1.67$ ) so that hypothesis is accepted. It means Organizational Factors such as Superiors' Support, Clarity of Purpose and Training positively affects cognitive conflict.

H3 Testing is: "The Organizational Factors such as Superiors' Support, Clarity of Purpose and Training give negative effects on affective conflict". The parameter coefficient is -0.355888 which means there is negative effects of Organizational Factors on affective conflict with statistic $t$ value of $1.702577>t$ table (significance $5 \%=1.67$ ) so that hypothesis is accepted. It means Organizational Factors such as Superiors' Support, Clarity of Purpose and Training give negative effect on affective conflict.

H4 Testing is: "Cognitive Conflict gives positive effect with SAKD usability". The parameter coefficient of 0.316308 means there is positive effect of cognitive conflict on SAKD usability. With statistic $\mathrm{t}$ value of $1.676421>\mathrm{t}$ table (significance $5 \%=1.67$ ) so that hypothesis is accepted. It means cognitive conflict gives positive effect on SAKD usability.

H5 Testing is: "Affective conflict gives negative effect on SAKD usability". The parameter coefficient of -0.184310 means there is negative effect of affective conflict on SAKD usability with statistic $t$ value of $1.753443>t$ table (significance $5 \%=1.67$ ) so that hypothesis is accepted. It means affective conflict gives negative effects on SAKD usability.

\section{Direct and Indirect Effect}

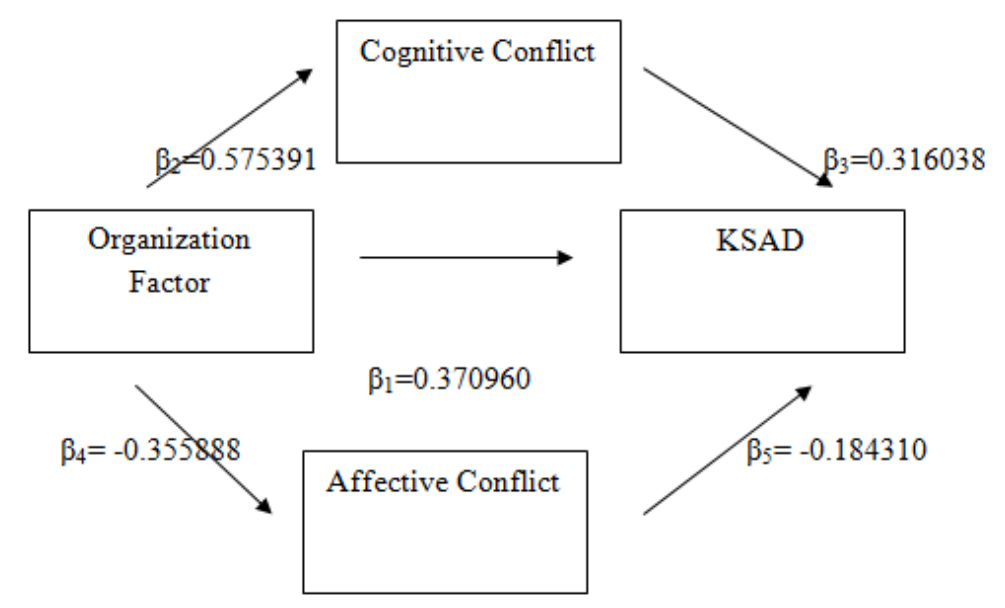

Figure 2

Direct and Indirect Effect 


\begin{tabular}{lcc}
\hline & Beta Coefficient & T value \\
\hline Direct effect of FO on & 0.370960 & 2.404270 \\
KSAD & 0.57391 & 6.723176 \\
Effect of FO $\rightarrow$ KK & 0.316308 & 1.676421 \\
Effect of KK $\rightarrow$ KSAD & -0.355888 & 1.702577 \\
Effect of FO $\rightarrow$ KA & -0.184310 & 1.753443 \\
Effect of KA $\rightarrow$ KSAD & &
\end{tabular}

According to regression equation on the table above, it can be seen that indirect effects can be calculated as follows:

\section{Indirect Effects:}

$$
\begin{array}{lll}
\text { FO } \rightarrow \text { KSAD } & =0.370960 \\
\text { FO } \rightarrow \text { KK } \rightarrow \text { KSAD } & =0.57391 \times 0.316308 & =0.181532 \\
\text { FO } \rightarrow \text { KA } \rightarrow \text { KSAD }=-0.355888 \times-0.184310 & =0.0655937
\end{array}
$$

Thus its regression coefficient of indirect effects both through KK and KA is smaller than its direct effects $(0.370960)$. So it can be said that $\mathrm{FO} \rightarrow \mathrm{KSAD}$ gives greater effect than through the affective conflict and the cognitive conflict. However, the cognitive conflict and the affective conflict can still be regarded as intervening although the effect is smaller than FO $\rightarrow$ KSAD.

\section{CONCLUSIONS}

From the results of discussion and analysis in the previous section, it can be concluded as follows:

1. There is positive effect of organizational factor on the usability of Regional Financial Accounting System.

2. There is positive effect of organizational factors on cognitive conflict such as Superiors' Support, Clarity of Purpose and Training.

3. There is negative effect of organizational factors on affective conflict of Organizational Factors such as Superiors' Support, Clarity of Purpose and Training.

4. There is positive effect of cognitive conflict on the usability of Regional Financial Accounting System.

5. There is negative effect of affective conflict on the usability of Regional Financial Accounting System. 


\section{IMPLICATIONS}

The implication could be addressed in this study are as follows:

1. At least the organization should consider organizational factors such as Superiors'

Support, Clarity of Purpose and Training because they are proven to give effect on the cognitive and the affective conflicts.

2. Must be able to ensure that the questionnaires sent are completely filled by the researchers' desired objects, further research should strengthen it by having interview or direct observation.

3. This study was only conducted at one time (cross-sectional), so there is possibility that individual behavior is changing over time.

For similar study in the future, it is suggested to extend the area of the sample or to add other variables that affect the usability of Regional Financial Accounting System.

\section{REFERENCES}

Agusti Tae Ferdinand. 2006. Metode penelitian Manajemen Edisi II. Semarang : Badan Penerbit Universitas Diponegoro.

Arikunto, Suharsimi. 2006. Prosedur penelitian (Suatu Pendekatan Praktik) : Suatu Pendekatan Praktek. Jakarta : Rineka Cipta.

Bandura. 1997. Sosial Cognitive Theory of Organizational Management, Academy of Management Review, Vol 14:361-384.

Chenhall, R.H. 2004. "The Role of Cognitif and Affective Conflict in Early Implementation of Activity-Based Cost Management". Behavioral Reaserch in Accounting 16:19.

Ghozali, Imam. 2008. Structural Equation Modeling Metode Alternatif dengan Partial Least Square. Semarang : Badan Penerbit Universitas Diponegoro.

Halim, Abdul. 2004. Otonomi Daerah,Penganggaran Daerah dan Korupsi. Kajian Ilmiah (Makalah) .

Ihyaul Ulum, MD. 2004. Akuntansi Sektor Publik: Sebuah Pengantar. Malang: Universitas Muhammadyah Malang.

Jamiyla. 2010. "Hubungan Faktor Sikap Dalam Implementasi SAPD Dengan Kualitas Informasi (Studi Kasus Pada Biro Keuangan Pemerintahan Provinsi Sumatera Selatan)". Ilmiah Volume 11 No.2.

Kadir, Abdul, 2003. Pengenalan Sistem Informasi. Yogyakarta: Penerbit Andi

Keputusan Menteri Dalam Negeri Nomor 29 Tahun 2002 Tentang Pedoman Pengurusan, Pertanggungjawaban Dan Pengawasan Keuangan Daerah Serta Tata Cara Penyusunan Anggaran Pendapatan Dan Belanja Daerah, Pelaksanaan Tata Usaha Keuangan Daerah Dan Penyusunan Perhitungan Anggaran Pendapatan Dan Belanja Daerah

Latifah, Lyna dan Arifin Sarbeni. 2007, "Faktor Keperilakuan Organisasi dalam Implementasi Sistem Akuntansi Keuangan Daerah". Simposium Nasional Akuntansi X, Makasar 26-28 Juli 2007. 
Mahmudi. 2007. Manajemen Kinerja Sektor Publik. Yogyakarta: Sekolah Tinggi Ilmu Manajemen YKPN.

Mardiasmo. 2002. Akuntansi Sektor Publik. Yogyakarta : ANDI.

Mardiasmo. 2006. "Perwujudan Transparansi dan Akuntabilitas Publik Melalui Akuntansi Sektor Publik: Suatu Sarana Good Governance". Jurnal Akuntansi Pemerintah, Vol. 2 No.1, Hal 1-17.

Masri, Singarimbun dan Sofyan. 1995. Metode penelitian Survey. Jakarta : LP3ES.

Mranani, Muji dan Beti Lestiorini. 2010. "Faktor keperilakuan organisasi terhadap kegunaan sistem akuntansi Keuangan daerah dengan konflik kognitif dan konflik afektif sebagai intervening". ILMIAH Volume I1 No.2.

Mulyadi. 2001. Sistem Akuntansi. Salemba empat : Yogyakarta.

Nurlaela, Siti dan Rahmawati. 2010. "Pengaruh Faktor Keperilakuan Organisasi Terhadap Kegunaan Sistem Akuntansi Keuangan Daerah Di Subosukawonosraten". Simposium Nasional Akuntansi XIII, Purwokerto.

Peraturan Pemerintah Republik Indonesia Nomor 11 Tahun 2001 Tentang Informasi Keuangan Daerah.

Peraturan Pemerintah Republik Indonesia Nomor 105 Tahun 2000 Tentang Pengelolaan Dan Pertanggungjawaban Keuangan Daerah.

Peraturan Pemerintah Republik Indonesia Nomor 108 Tahun 2000 Tentang Tata Cara Pertanggungjawaban Kepala Daerah

Republik Indonesia. Instruksi Presiden Republik Indonesia Nomor 7 Tahun 1999 Tentang Akuntabilitas Kinerja Instansi Pemerintah

Republik Indonesia. Peraturan Menteri Dalam Negri Nomor 13 Tahun 2006 tentang pedoman Pengelolaan Keuangan Daerah.

Republik Indonesia. Peraturan Pemerintah Nomor 24 Tahun 2005 tentang Standar Akuntansi Pemerintahan.

Republik Indonesia. Peraturan Pemerintah Nomor 58 Tahun 2005 tentang Pengelolaan Keuangan Daerah.

Republik Indonesia. Peraturan Menteri Dalam Negeri Nomor 59 Tahun 2007 tentang Perubahan Atas Peraturan Menteri Dalam Negeri Nomor 13 Tahun2006 Tentang Pedoman Pengelolaan Keuangan Daerah Menteri Dalam Negeri.

Republik Indonesia . Undang-undang No. 1 Tahun 2004 tentang Perbendaharaan Negara.

Republik Indonesia . Undang-undang No.15 Tahun 2004 tentang Pemeriksaan Pengelolaan Dan Tanggungjawab Keuangan Negara.

Republik Indonesia . Undang-undang No.17 Tahun 2003 tentang Keuangan Negara

Republik Indonesia . Undang-undang RI. No. 32 Tahun 2004 tentang Pemerintah Daerah

Republik Indonesia . Undang-undang RI. No. 33 Tahun 2004 Perimbangan Keuangan antara Pemerintah Pusat dan Daerah.

Rina Trisnawati. 1998. Pertimbangan perilaku dan Faktor Penentu Keberhasilan Pengembangan Sistem Informasi, Kajian Bisnis No. 14 Mei - September. Mangkunegara, A.P. 2002. Manajemen Sumber Daya Perusahaan. ROSDA. Bandung

Sahusilawane, Wildoms. 2011. "Pengaruh FAkor Keperilakuan Organisasi Dalam Penggunaan Sistem Informasi Keuangan Daerah Terhadap Kinerja Individual".

Sekaran, Uma 2006. Metodologi Penelitian Untuk Bisnis. Jakarta: Salemba Empat.

Sugiarto. 2003. Metode Penelitian Kuantitatif dan R\&D. Bandung : CV. Alfabeta.

Suwardjono. 2005. Teori Akuntansi : Perekayasaan Pelaporan Keuangan, Edisi ketiga. Yogyakarta : BPFE. 
http://achenkpanyalai.blogspot.com/2011/11/normal-0-false-false-false-en-us-X-none.html http://en.wikipedia.org/wiki/Public_choice_theory http://en.wikipedia.org/wiki/Social_cognitive_theory http://en.wikipedia.org/wiki/Contingency_theory http://eprints.uny.ac.id/7721/3/BAB\%202-07409134051.pdf http://id.wikipedia.org/wiki/Daftar_kecamatan_dan_kelurahan_di_Kota_Semarag http://keyturns.wordpress.com/2012/11/14/akuntansi-dan-laporan-keuangan http://pondokskripsi.wordpress.com/2009/12/20/perancangan-sistem-informasi-akuntansipenerimaan-kas-pada-cv-vettya-karya-nugraha/ http://www.auditorindonesia.com/aicom/index.php/en/browsearticles/8auditissues/38koruptor-beraksi-lewat-laporan-keuangan 